\title{
Sectoral Business Cycle Synchronization in the European Union*
}

\author{
António Afonso, ${ }^{\$}$ Davide Furceri ${ }^{\star}$
}

January 2007

\begin{abstract}
This paper analyses sectoral business cycle synchronization in an enlarged European Union using annual data for the period 1980-2005. In particular, we try to identify which sector for each country is driving the aggregate output business cycle synchronization. Overall, the sectors that provide the most relevant contribution are Industry, Building and Construction, and Agriculture, Fishery and Forestry. In contrast, the Services sector, the largest one in terms of valued added share, shows a relative low business cycle synchronization and volatility, implying that it contributes only marginally to the aggregate output business cycle synchronization.
\end{abstract}

JEL: E32; F15; F41; F42

Keywords: EMU Enlargement, Stabilisation, Synchronization, Sectoral Business Cycle.

\footnotetext{
* We are grateful to Vito Tanzi for helpful suggestions and Renate Dreiskena for research assistance. The opinions expressed herein are those of the authors and do not necessarily reflect those of the the ECB or the Eurosystem.

\# European Central Bank, Directorate General Economics, Kaiserstraße 29, D-60311 Frankfurt am Main, Germany, email: antonio.afonso@ecb.int.

\$ UECE - Research Unit on Complexity in Economics; Department of Economics, ISEG/TULisbon Technical University of Lisbon, R. Miguel Lupi 20, 1249-078 Lisbon, Portugal. UECE is supported by FCT (Fundação para a Ciência e a Tecnologia, Portugal), email: aafonso@iseg.utl.pt.

${ }^{+}$University of Palermo, Department of Economics, Italy.

- University of Illinois at Chicago. Address: Department of Economics (M/C 144), 601 S. Morgan Street, Chicago, 60607, Illinois. Email:dfurce1@uic.edu, dfurceri@yahoo.it Telephone/Fax: +1-3129962683/ +13129963344. The author would like to thank the Fiscal Policies Division of the ECB for its hospitality.
} 


\section{Introduction}

On 1 May 2004 the European Union (EU) welcomed ten new members: the Czech Republic, Estonia, Cyprus, Latvia, Lithuania, Hungary, Malta, Poland, Slovenia and Slovakia. In addition, two other countries, Bulgaria and Romania, will join the EU on January 2007, and other countries are at various stages of candidacy for membership in the EU. It is likely that all these countries will benefit from joining in the future the European and Monetary Union (EMU) in terms of inflation bias reduction, higher exchange rate stability, lower interest rates, and higher growth. Therefore, a relevant question is whether these economies should also expect to have high costs from EMU membership. The theory of the Optimum Currency Area, first developed by Mundell (1961), and including the classical contributions of McKinnon (1963) and Kenen (1969) stresses the importance of international linkages between the members of the monetary union to face the loss of the country-independent monetary policy to smooth output fluctuations. ${ }^{1}$

To the extent that the monetary policy would have contributed to stabilization of cyclical fluctuations in the past, the loss of the exchange rate control and of the independent monetary policy can be seen as the stabilisation cost in joining a monetary union. Moreover, it has been shown in the literature that this stabilisation cost is a decreasing function of the correlation between the cyclical output of the member country and the cyclical output of the anchor country (in this case the EMU as a whole). Intuitively, if the business cycle of a country is very highly correlated with the EMU-wide cyclical output, then countercyclical monetary policy conducted by the European Central Bank will be a very close substitute for the country independent monetary policy. Moreover, business cycle synchronization also has important implications for the ability to implement a common monetary policy.

The main purpose of this paper is to analyse sectoral business cycle synchronization in an enlarged European Union. In particular, we first ask whether the business cycles of the new EU countries are synchronized and compare them with those of EMU members, using annual data for the period 1980-2005. Second we analyse how business cycle

\footnotetext{
${ }^{1}$ For some recent contributions see Alesina and Barro(2002), Alesina, Barro and Tenreyro (2002), Corsetti and Pesenti (2002).
} 
synchronization evolves over time. Third, we try to identify which sector for each country is driving the aggregate output business cycle synchronization.

The results of the paper show that while for some countries (such as Cyprus, Hungary and Malta) EMU membership will be not costly, for the other countries with negative or negligible business cycle synchronization the stabilization cost could be relevant, at least in the short-run. However, business cycle synchronization seems to have increased over time, suggesting that these costs could be become not relevant in the next future. In terms of sectoral decomposition, the results suggest that, although for each country is possible to identify which sector is able to explain more the aggregate output business cycle synchronization, overall, Industry, Building and Construction, and Agriculture, Fishery and Forestry sectors provide the most relevant contribution. On the other hand, the Services sector depicts relatively low business cycle synchronization.

The remainder of the paper is organized as follows. In Section Two we present a brief literature review of the importance of business-cycle synchronization, particularly for the EMU. In Section Three, we present the empirical methodology used to evaluate aggregate and sectoral output business cycle synchronization. Section Four reports the results obtained, and finally, Section Five summarises the paper's main findings.

\section{Literature Review}

The literature on business-cycle synchronization in Europe (and how it compares to the U.S.) is vast. Bayoumi and Eichengreen (1993) found that demand and supply shocks are more correlated between states in the U.S. than in Europe, and that the U.S. states adjust more quickly to economic fluctuations than European countries. Using a different methodology, Wynne and Koo (2000) also found that business cycles are more aligned in the U.S. than in the euro area (of 11 members). Other authors, such as Clark and Shin (1998) and Clark and Van Wincoop (2001), focused on both within-country and crosscountry synchronization. They found that average within-country cyclical output correlations are larger than cross-country correlations, for both the U.S. and European countries (and again that business cycles are more synchronized in the U.S. than in Europe). Recently, Peiró (2004), examining the existence of asymmetries in industrial 
production in seven European countries for the period 1957-1998, finds that several of these countries have aligned business cycles.

Other studies have looked at changes in correlation patterns over time. Angeloni and Dedola (1999) found that the output correlation between Germany and other European countries has clearly increased during 1993-1997. Fatás (1997), using annual employment growth rates for regions of France, Germany, Italy, and the UK, found that the average correlation with aggregate EU-12 employment growth has increased from 1966-1979 to 1979-1992. Furceri and Karras (2006), analyzing cyclical output for the EU-15 countries found that business cycle synchronization has also increased for many countries after the creation of the EMU. In particular, this increase in synchronization is present in all components of aggregate demand, as well as two supply-side variables, but it is more pronounced in the trade components (imports and, particularly, exports). They also showed that the increase in trade within the EMU area is at least partly responsible for the increase in cyclical synchronization.

The literature has also considered the implications of the EMU for fiscal policy. In fact, unlike other monetary unions, the EMU does not have a central fiscal authority, and stabilisation of shocks is left to the responsibility of the domestic fiscal policies of the EMU members. However, the literature has shown that the ability of the EMU members' national fiscal policies to smooth shocks is very modest. ${ }^{2}$ One implication of this is that business-cycle synchronization is extremely important in the EMU not only because it reduces the probability of asymmetric shocks, but also because it makes it plausible to expect the European Central Bank (ECB) to respond to aggregate shocks and to implement stabilising interventions with greater ease.

The literature is much thinner on the analysis of sectoral business cycle synchronization. We believe that this is an important element and it would provide useful policy indications, since it would enable to identify which sector for each country is driving the aggregate output to be more or less synchronized with EMU-wide business cycle. Thus, the analysis carried out in the following of this paper has the purpose to extend the literature and provide some insights in understanding business cycle synchronization.

\footnotetext{
${ }^{2}$ See, for example, Galì and Perotti (2003), Afonso and Furceri (2006).
} 


\section{Empirical Methodology}

We obtain the output business cycle measures by detrending the series of real GDP. Four different methods are used to detrend the output series of each country $i$ and estimate its cyclical component. The first measure is simple differencing (growth rate of the real GDP).

The second and the third method use the Hodrick-Prescott (HP) filter, proposed by Hodrick and Prescott (1980). The second method consists of using the value recommended by Hodrick and Prescott for annual data for the smoothness parameter ( $\lambda$ ) equal to 100 . The third method consists to consider the smoothness parameter $(\lambda)$ equal to 6.25 . In this way, as pointed out by Ravn and Uhlig (2002), the Hodrick-Prescott filter produces cyclical components comparable to those obtained by the Band-Pass filter. The fourth method makes use of the recently popular Band-Pass (BP) filter proposed by Baxter and King (1999), and evaluated by Stock and Watson (1999) and Christiano and Fitzgerald (2003) that also compares its properties to those of the HP filter. ${ }^{3}$

While minor differences among the results obtained by the three filters are not difficult to detect (for example, differencing generally produces the most volatile series, while the BP the smoothest), the main characteristics are remarkably similar. This robustness will be formally assessed by the estimations of the empirical section.

In practice, we measure GDP busyness cycle synchronization for each country as the correlation between the country's cyclical component, $c_{i}$, and the EMU's cyclical component, $c_{E M U}$ :

$$
\operatorname{corr}\left(c_{i}, c_{E M U}\right) \text {. }
$$

Successively, in order to identify which sector $j$ for each country $i$ is mainly responsible for the aggregate output business cycle synchronization, we first compute the country's sectoral cyclical components, $c_{i}^{j}$, and then we compute the correlation between these components and the EMU's cyclical component:

\footnotetext{
${ }^{3}$ See Appendix 1 for an additional descripion of the filtering methods used in the paper.
} 


$$
\operatorname{corr}\left(c_{i}^{j}, c_{E M U}\right)
$$

Moreover, to determine the relative weight of each sector in the computation of the aggregate output business cycle synchronization, we compute the standard deviations of the country's sectoral cyclical components. It is clear in fact, that the higher is the volatility of a given sector, the more relevant is this sector in the computation of the aggregate output business cycle synchronization.

In particular, if we could approximate ${ }^{4}$ the country's GDP cyclical component $c_{i}$ as the sum of the sectoral value added cyclical components

$$
c_{i} \cong \sum_{j} c_{i}^{j}
$$

then we could decompose the correlation between the country's cyclical component and the EMU's cyclical component, as a weighted average of the correlations between the country's sectoral cyclical components $c_{i}^{j}$ and the EMU's cyclical component:

$$
\operatorname{corr}\left(c_{i}, c_{E M U}\right) \cong \sum_{j} w_{i}^{j} \operatorname{corr}\left(c_{i}^{j}, c_{E M U}\right) .
$$

The weights, $w_{i}^{j}$, are represented by the share of output business cycle volatility (measured by the standard deviation of the cyclical components) attributable to each sector:

$$
w_{i}^{j}=\frac{\sigma_{i}^{j}}{\sigma_{i}} .
$$

\section{Empirical Analysis}

\subsection{Data}

We use data from the European Commission Annual Macro-economic Database (AMECO). ${ }^{5}$ Our dataset covers 28 countries (the 12 current EMU countries, the 3 old EU

\footnotetext{
${ }^{4}$ Which is not possible due to the nonlinearity of the filtering methods.

${ }^{5}$ See the Annex for a description of data sources and availability.
} 
countries which have not adopted the euro, the 10 new EU members, and 3 prospective members, Bulgaria, Romania and Turkey) from 1980 to 2005.

The income variable we use to determine output business cycle synchronization is real GDP in 2000 constant prices. We use data for Gross Value Added for the Industry (not including Building and Construction), Agriculture, Forestry and Fishery, Building and Construction, and Services sectors to decompose output synchronization into sectoral business cycle synchronization. ${ }^{6}$

\subsection{Output Business Cycle Synchronization}

We calculate the correlation coefficient of each country's cyclical component of real GDP with that of EMU, as a whole, using the HP filter with smoothness parameter equal to 6.25. Even though the estimated correlations vary according to the detrending method used, the implied rankings are very similar, regarding the overall period, the highest Spearman's rank correlation coefficients is 0.936 (BP, HP6.25) and the lowest is 0.776 (Diff, HP100), as can be seen from Table 1 .

\section{[Insert Table 1 here]}

Table 2 considers three different periods of analysis. The first is from 1980 to 1992 and considers the EU15 countries. The second is from 1993 to 2005 and applies to all 28 countries. The third is the overall period from 1980 to 2005 . In relation to the overall period, we can see that for most EMU countries business cycle is relatively well synchronized, even if for some countries (namely Finland) there is an almost zero correlation with the EMU economy as a whole.

\section{[Insert Table 2 here]}

Looking at the period 1993-2005, France shows an almost perfect correlation with the EMU economy. However, comparing the 12 euroized countries with the 3 (old) non-euro economies, it is difficult to establish a systematic relationship. In fact, Denmark, Sweden

\footnotetext{
${ }^{6}$ We use the GDP deflator to express the variables in 2000 constant prices.
} 
and the UK appear to be more synchronized with the EMU-wide cycle than some euro area members, such as Greece and Finland.

The new EU countries show a generally higher synchronization with the EMU than the candidate countries. In particular, there are some new EU countries (such as Cyprus, Hungary and Malta) already well synchronized with the EMU, and with correlations comparable to, or even higher than, those of some of the old members. On the other hand, several new EU countries (such as Estonia, Lithuania and Slovakia) exhibit negative correlations, as do two of the three prospective EU members (Romania and Turkey). The other new EU and accession countries (namely, Czech Republic, Latvia, Poland, Slovenia and Bulgaria) show a very negligible, even if positive, correlation. Overall, we can argue that while for some countries as Cyprus, Hungary and Malta, EMU membership will be not costly, for the other countries with negative or negligible business cycle synchronization the stabilisation cost could be relevant, at least in the short-run.

Focusing on the 1980-2005 period is only fully feasible for the old EU members, but this can be used to indicate how the correlations have changed for these countries, and how they could change for the prospective Member States. The most striking fact to emerge from this exercise is that the degree of synchronization with EMU has remarkably increased for all countries (with the exception of Germany, where it remained broadly similar). This result can be largely attributed to the achievement of a more integrated market since 1992, and to an increase in trade as pointed out by Furceri and Karras (2006). But, perhaps more interestingly, the results show that the increased synchronization has been at least as large in the non-euro area as in the euro area economies.

Thus, it is likely to be the case that as the intra-EMU share of trade for the new EU members increases, business cycles will become more synchronized. ${ }^{7}$ Moreover as pointed out by Frankel and Rose (1998), Rose and Engel (2002), and Rose (2005), the business cycle synchronization between the candidate countries and the currency union (or the anchor country) is endogenous, and it will tend to increase once the country will be part of the currency union.

\footnotetext{
${ }^{7}$ See also Artis and Zhang (1997).
} 


\title{
4.3. Sectoral Business Cycle Synchronization
}

\author{
Industry (excluding Building and Construction)
}

In Table 3, we calculate for each country the correlation coefficient between the industry value added cyclical component and that of the EMU-wide GDP, and the standard deviation of the Industry value added cyclical component (using the HP filter with smoothness parameter equal to 6.25 for consistency). For each country, we report also the share of total value added generated by the Industry sector. We also consider in Table 3 three different periods of analysis: the first is from 1980 to 1992 and considers the EU15 countries: the second is from 1993 to 2005 and applies to all 28 countries; and the third is the overall period from 1980 to 2005 .

\section{[Insert Table 3 here]}

Looking at the shares of this sector we can see that industry generated around one fourth of the total valued added (looking at the period where data for all 28 countries are available, it ranges from 13.0 percent for Cyprus to 32.4 percent for Ireland). Moreover, comparing the two sub periods it emerges clearly that this share is diminishing over time (in favour of the service sector as we will see in the following of our analysis).

In relation to the overall period, we can see that for some countries such as France, Germany, Ireland, Italy and Spain, the Industry sector synchronization with the EMU-wide GDP is relatively high. Moreover a sizeable volatility of this sector in these countries contributes to provide a significant contribution in the total GDP synchronization. In contrast, for other countries such as Austria, Greece and Netherlands, the industry valued added cyclical component is weakly correlated with the EMU-wide business, and in the case of Greece it is also worsen by the relative high volatility.

However, looking at the two sub periods we can see an increase in the Industry business cycle synchronization for many EMU countries, contributing to the increase in GDP business cycle synchronization found in the previous section. 
Finally analyzing the period 1993-2005 where the results for all 28 countries are available, we can see that while the new EU and candidate members show a higher volatility in the Industry sector, there is no particular difference between EU and EMU countries. In fact, while some of them (such as Cyprus and UK) are more synchronized than most of the EMU members, other countries (Hungary, Slovakia, Czech Republic and Estonia) show a negative correlation.

\section{Building and Construction}

In Table 4, we present the results in terms of business cycle synchronization, volatility and share of total value added for the Building and Construction sector. Looking at the shares we can see that the valued added contribution generated by the Building and Construction sector is relatively small around 6\%. Moreover, comparing the two sub periods it emerges that for many EU15 countries (with the exception of Spain, Austria and Portugal) this share is diminishing over time.

\section{[Insert Table 4 here]}

In relation to the overall period, we can see that for some countries such as Ireland, Belgium and Sweden, the Building and Construction sector is well synchronization with the EMU-wide GDP is relatively high and relatively volatile, providing a significant contribution in the total GDP synchronization. In contrast, for other countries such as Austria, this sector is negatively synchronized with the EMU-wide GDP, and for many other countries the correlation is negligible.

Looking at the two sub periods we can not observe, as in the case of the Industry sector, a systematic increase in business cycle synchronization (with the exception of Ireland, Spain, the UK, and Portugal). Additionally, analyzing the period 1993-2005, we can see that while the new EU and candidate members show a higher volatility in the Building and Construction sector, they have lower business cycle synchronization. In fact, most of them show a negative or quite negligible correlation.

Furthermore, it seems that for some countries such as Spain and Portugal, characterized by an increasing share and high and increasing business cycle synchronization in Building 
and Construction, this sector contributes significantly and positively to the computation of total GDP business cycle synchronization.

Agriculture, Fishery and Forestry

In Table 5, we present the results in terms of business cycle synchronization, volatility and share of total value added for the Building and Construction sector. In terms of the share of this sector in total added value, we can see that it is quite small (with the exception of Greece, Portugal, Ireland, and Spain), and is decreasing over time.

In relation to the overall period, we can see that for most of the EU15 countries the Agriculture, Fishery and Forestry sector synchronization with the EMU-wide GDP is relatively small. However, it is more than compensated, in terms of relevance in the computation of the aggregate output business cycle synchronization, by a high volatility (compared to the other sectors).

\section{[Insert Table 5 here]}

Looking at the two sub periods we can see that while synchronization increased for some countries (for example, Austria and Germany) it decreased for many others (especially Ireland). In contrast business cycle volatility seems to have remained quite stable.

Finally analyzing the period 1993-2005, again we can see that the new EU and candidate members show a higher volatility than in the industry sector, but there are no major differences between the EU and the EMU countries in terms of business cycle synchronisation. Latvia seems to be an exception, being characterized by significant synchronization and high volatility. Overall, although this sector is characterized by relatively low business cycle synchronization, it is very volatile, contributing nevertheless to GDP business cycle synchronization. 
In Table 6, we present the same set of results analyzed for the Services sector. In terms of the share in total valued added, we can observe that the Services sector is the most relevant sector in the European Union, around 60 percent, and its share is increasing over time.

\section{[Insert Table 6 here]}

Analysing the result in terms of GDP business cycle synchronization, in relation to the overall period, we can see that for Italy, Spain and Sweden the Services sector is well synchronization with the EMU-wide GDP. For the other countries the correlation is either negative (as in the case of Austria, Netherlands and Denmark) or negligible. Volatility is also is relatively low compared to the other sectors, implying a low weight in the contribution of the aggregate output business cycle synchronization.

Looking at the two sub periods we can see that while synchronization increased for some countries (especially France, and the Netherlands), significant decreases were recorded for Greece and Italy. For the period 1992-2005, where the results for all 28 countries are available, we can see that the new EU and candidate members show an higher volatility in the Services sector (as in the other three sectors), but again there is no particular difference between EU and EMU countries in terms of sectoral synchronization. In fact, while countries such as Cyprus, Malta, and the UK are more synchronized than most of the EMU members, other countries (such as Hungary, Slovakia, Czech Republic and Estonia) show a negative correlation.

Overall, it seems that due to the low business cycle synchronization and the relative low volatility, this sector is the one that (compared to the other three sectors) contributes less to the aggregate output business cycle synchronization.

To conclude our analysis, we can point out that, although for each country is possible to identify which sector is able to explain more the aggregate output business cycle synchronization, overall, the sectors that provides the most relevant contribution are Industry, Building and Construction, and Agriculture, Fishery and Forestry. In contrast, although the Services sector is the largest one in terms of valued added share, it shows 
relative low business cycle synchronization and volatility, implying that it contributes only marginally to the aggregate output business cycle synchronization. ${ }^{8}$

\section{Conclusion}

The new EU member states are expected to join in the future the single currency. It is likely, that all these countries will receive benefits in terms of inflation bias reduction, higher exchange rate stability, lower interest rates, and higher growth from joining the EMU. The theory of the Optimum Currency Area stresses the importance of business cycle synchronization (the business-cycle correlation between the candidate's economy and that of the euro area as a whole) to face the loss of the country-independent monetary policy to smooth output fluctuations.

The results of the paper show that there are some new EU countries (such as Cyprus, Hungary and Malta) already well synchronized with the EMU, and with correlations comparable to, or even higher than, those of some of the old members. On the other hand, several new EU countries (such as Estonia, Lithuania and Slovakia) exhibit negative correlations, as do two of the three prospective EU members (Romania and Turkey). However, it is worthwhile mentioning that this analysis can give useful indications in terms of stabilization costs only in the short-medium term. In fact, as it has been shown by Frankel and Rose (1998), business cycle synchronization is likely to increase for the EU countries once they would join the EMU, as EU membership could increase intra-EMU trade allowing business cycles to become more synchronized. It is significant that our analysis also shows that business cycle synchronization has increased for all the EU15 countries after the achievement of the Single Market (1991).

Successively, we tried to identify for each country which sector is driving the aggregate output business cycle synchronization. In particular, we considered four sectors: Industry (not including Building and Construction); Agriculture, Forestry and Fishery; Building and Construction; and Services sectors.

\footnotetext{
${ }^{8}$ Additionally, we report in Appendix 2 results for sectoral business cycle synchronization within country, linked with the EMU-sector synchronization via the EMU-country synchronization.
} 
For each of this sector we computed the total valued added shares, the sectoral business cycle synchronization and volatility. Overall, it seems that while the Services sector is the largest one in terms of valued added share, it shows relative low business cycle synchronization and volatility, implying that it contributes only marginally to the aggregate output business cycle synchronization. In contrast, the other three sectors are overall quite synchronized and relatively volatile, implying a higher and more relevant contribution.

Moreover, for each country is possible to identify which sector is able to explain more the aggregate output business cycle synchronization. For example, for countries like Germany, France, Italy, Cyprus and UK the Industry sector is the one that has the higher business cycle synchronization. For countries like Belgium, Spain (especially in the last decade) and Sweden the Building and Construction sector is the more relevant. Finally the Agriculture, Fishery and Forestry sector is particularly important for the Czech Republic and Latvia. 


\section{References}

Afonso, A and Furceri D. (2006). "EMU enlargement, stabilization cost and insurance mechanisms". Manuscript.

Alesina, A. and Barro, R. (2002). "Currency unions", Quarterly Journal of Economics 117, 409-436.

Alesina, A.; Barro, R. and Tenreyro, S. (2002). "Optimal currency areas", NBER Working Papers, 9072.

Angeloni, I. and Dedola, L. (1999). "From the ERM to the Euro: nee evidence on economic and policy convergence among EU countries", European Central Bank Working Paper 4.

Artis, M. and Zhang, W. (1997). "International business cycles and the ERM: Is there a European business cycle," International Journal of Finance and Economics, 2 (1), 1-16.

Bayoumi, T. and Eichengreen B (1993) Shocking aspects of the European monetary integration, in: Torres F, Giavazzi F (Ed.) Adjustment and Growth in the European Monetary Union. Cambridge University Press: Cambridge, 193-229.

Baxter, M. and King, R. (1999). "Measuring Business Cycles: Approximate Band-Pass Filters for Economic Time Series", Review of Economics and Statistics, 81 (4), 575-593.

Christiano, L. and Fitzgerald, T. (2003). "The Band Pass Filter," International Economic Review, 4 (2), 435-465.

Clark, T. and Van Wincoop, E. (2001). "Borders and business cycles", Journal of International Economics, 55, 59-85.

Clark, T. and Shin, K. (1998). "The sources of fluctuations within and across countries", Federal Reserve Bank of Kansas City, Research Working Paper 4.

Corsetti, G. and Pesenti, P. (2002) "Self-validating optimum currency areas," NBER Working Papers, 8783.

Fatás, A. (1997). "EMU: countries or regions: lessons from the EMS experience," European Economic Review, 41 (3-5), 743-751.

Furceri, D. and Karras, G. (2006). "Business Cycle Synchronization in the EMU", Applied Economics (forthcoming).

Galì, J and Perotti, R. (2003). "Fiscal Policy and Monetary Integration in Europe", Economic Policy, 18, 533-572.

Frankel, J. and Rose, A. (1998). "The Endogeneity of the Optimum Currency Area Criteria,” Economic Journal 108, 1009-1025.

Hodrick, R. and Prescott, E. (1980) "Postwar U.S. Business Cycles: An Empirical Investigations”, Discussion Papers 451, Carnegie Mellon University. 
Kenen, R. (1969) "The theory of optimum currency area: an eclectic view," in: R. Mundell and A. Swoboda, (eds.), Monetary problems of the international economy, Chicago, Univeristy of Chicago Press.

Kydland, F. and Prescott. E. (1977). "Rules Rather Than Discretion: The Inconsistency of Optimal Plans," Journal of Political Economy, 85, 473-490.

McKinnon, R. (1963). “Optimum currency areas," American Economic Review 53, 717 725 .

Mundell, R. (1961) "A theory of optimum currency areas," American Economic Review $82,942-963$.

Peiró, A. (2004). "Are Business Cycle Asymmetric? Some European Evidence", Applied Economics, 36, 335-342.

Ravn, M. and Uhlig, H. (2002). "On Adjusting the Hodrick-Prescott Filter for the Frequency of Observations". Review of Economics and Statistics, 84 (2), 371-380.

Rose, A. and Stanley, T. (2005) "A meta analysis of the effect of common currencies on international trade," Journal of Economic Surveys, 19 (3), 347-365.

Rose, A. and Engel, C. (2002). "Currency unions and international integration," Journal of Money, Credit and Banking 34, 1067-1089.

Stock, J. and Watson, M. (1999). "Business Cycle Fluctuations in U.S. Macroeconomic Time Series", in Taylor, J. and Woodford, M. (eds.), Handbook of Macroeconomics, vol 1, 3-64, Elsevier.

Wynne, M. and Koo, J. (2000). "Business cycles under monetary union: a comparison of the EU and US", Economica, 67, 347-374. 
Table 1 - Spearman's rank correlation matrix

\begin{tabular}{lcccc}
\hline & HP6.25 & HP100 & BP & Diff \\
\hline HP6.25 & 1.000 & & & \\
HP100 & 0.936 & 1.000 & & \\
BP & 0.847 & 0.855 & 1.000 & \\
Diff & 0.839 & 0.776 & 0.788 & 1.000 \\
\hline
\end{tabular}

Table 2 - Business cycle synchronisation (vis-à-vis EMU)

\begin{tabular}{|c|c|c|c|}
\hline & $1980-1992$ & $1993-2005$ & $1980-2005$ \\
\hline & \multicolumn{3}{|c|}{ EMU countries } \\
\hline Austria & 0.534 & 0.793 & 0.647 \\
\hline Belgium & 0.692 & 0.832 & 0.762 \\
\hline Finland & $0.582 *$ & 0.478 & $0.509^{*}$ \\
\hline France & 0.615 & 0.977 & 0.786 \\
\hline Germany & 0.763 & 0.678 & 0.696 \\
\hline Greece & 0.601 & 0.441 & 0.554 \\
\hline Ireland & 0.285 & 0.645 & 0.465 \\
\hline Italy & 0.539 & 0.810 & 0.674 \\
\hline Luxembourg & 0.419 & 0.745 & 0.570 \\
\hline Netherlands & 0.542 & 0.875 & 0.692 \\
\hline Portugal & 0.341 & 0.733 & 0.507 \\
\hline \multirow[t]{2}{*}{ Spain } & 0.506 & 0.871 & 0.662 \\
\hline & \multicolumn{3}{|c|}{ Other EMU } \\
\hline Czech Republic & & 0.031 & \\
\hline Denmark & 0.043 & 0.569 & 0.258 \\
\hline Estonia & & -0.220 & \\
\hline Cyprus & & 0.541 & \\
\hline Latvia & & 0.238 & \\
\hline Lithuania & & -0.032 & \\
\hline Hungary & & 0.789 & \\
\hline Malta & & 0.698 & \\
\hline Poland & & 0.247 & \\
\hline Slovenia & & 0.412 & \\
\hline Slovakia & & -0.673 & \\
\hline Sweden & 0.164 & 0.695 & 0.443 \\
\hline \multirow[t]{2}{*}{ UK } & -0.137 & 0.594 & 0.042 \\
\hline & \multicolumn{3}{|c|}{ Candidate countries } \\
\hline Bulgaria & & 0.342 & \\
\hline Romania & & -0.242 & \\
\hline Turkey & & -0.273 & \\
\hline
\end{tabular}

Note: Hodrick-Prescott Filter with smoothness parameter equal to 6.25.

* We did not consider the years 1991 and 1992 to take into account the Finland crisis in the early 1990s. 
Table 3 - Industry (excluding Building and Construction) contribution to business cycle synchronisation (vis-à-vis EMU)

\begin{tabular}{|c|c|c|c|c|c|c|c|c|c|}
\hline & \multicolumn{3}{|c|}{$\begin{array}{l}\text { Business Cycle } \\
\text { Synchronization }\end{array}$} & \multicolumn{3}{|c|}{ Volatility } & \multicolumn{3}{|c|}{$\begin{array}{l}\text { Sector share in the country } \\
\text { added value }(\%)\end{array}$} \\
\hline & $80-92$ & $93-05$ & $80-05$ & $80-92$ & $93-05$ & $80-05$ & $80-92$ & $93-05$ & $80-05$ \\
\hline & \multicolumn{9}{|c|}{ EMU countries } \\
\hline Austria & -0.169 & 0.706 & 0.284 & 0.014 & 0.017 & 0.015 & 26.054 & 22.612 & 24.402 \\
\hline Belgium & 0.174 & 0.453 & 0.349 & 0.025 & 0.023 & 0.023 & 26.333 & 21.970 & 24.239 \\
\hline Finland & $0.464^{*}$ & 0.430 & $0.447 *$ & $0.055^{*}$ & 0.061 & $0.058^{*}$ & 27.361 & 26.628 & 27.009 \\
\hline France & 0.569 & 0.815 & 0.679 & 0.020 & 0.016 & 0.018 & 22.311 & 17.704 & 20.100 \\
\hline Germany & 0.501 & 0.801 & 0.668 & 0.017 & 0.016 & 0.016 & 32.747 & 25.135 & 29.093 \\
\hline Greece & 0.418 & -0.185 & 0.175 & 0.047 & 0.021 & 0.036 & 20.119 & 14.690 & 17.513 \\
\hline Ireland & & 0.527 & & & 0.040 & & & 32.428 & \\
\hline Italy & 0.669 & 0.342 & 0.547 & 0.027 & 0.031 & 0.030 & 27.434 & 23.518 & 25.554 \\
\hline Luxembourg & 0.135 & 0.592 & 0.313 & 0.035 & 0.028 & 0.031 & & 13.624 & \\
\hline Netherlands & -0.001 & 0.490 & 0.196 & 0.023 & 0.019 & 0.020 & 24.459 & 19.825 & 22.235 \\
\hline Portugal & 0.585 & 0.233 & 0.379 & 0.047 & 0.027 & 0.039 & 22.116 & 20.033 & 21.116 \\
\hline Spain & 0.617 & 0.442 & 0.563 & 0.041 & 0.030 & 0.037 & 26.578 & 20.909 & 23.857 \\
\hline Minimum & -0.169 & -0.185 & 0.175 & 0.014 & 0.016 & 0.015 & 20.119 & 14.690 & 17.513 \\
\hline \multirow[t]{2}{*}{ Maximum } & 0.669 & 0.815 & 0.679 & 0.055 & 0.061 & 0.058 & 32.747 & 32.428 & 29.093 \\
\hline & \multicolumn{9}{|c|}{ Other EU } \\
\hline Cyprus & & 0.656 & & & 0.007 & & & 13.003 & \\
\hline Czech Republic & & -0.108 & & & 0.052 & & & 31.315 & \\
\hline Denmark & 0.021 & 0.586 & 0.325 & 0.025 & 0.023 & 0.024 & 20.831 & 20.257 & 20.556 \\
\hline Estonia & & -0.060 & & & 0.028 & & & 21.908 & \\
\hline Hungary & & -0.193 & & & 0.081 & & & 26.623 & \\
\hline Latvia & & 0.173 & & & 0.054 & & & 21.002 & \\
\hline Lithuania & & 0.428 & & & 0.109 & & & 25.239 & \\
\hline Malta & & 0.510 & & & 0.049 & & & 23.080 & \\
\hline Poland & & 0.009 & & & 0.088 & & & 25.704 & \\
\hline Slovakia & & -0.122 & & & 0.031 & & & 28.767 & \\
\hline Slovenia & & 0.350 & & & 0.080 & & & 30.468 & \\
\hline Sweden & 0.393 & 0.349 & 0.374 & 0.039 & 0.062 & 0.051 & 24.841 & 24.093 & 24.482 \\
\hline UK & 0.043 & 0.633 & 0.303 & 0.036 & 0.047 & 0.041 & 30.831 & 22.660 & 26.909 \\
\hline Minimum & 0.021 & -0.193 & & 0.025 & 0.007 & 0.024 & 20.831 & 13.003 & 20.556 \\
\hline \multirow[t]{2}{*}{ Maximum } & 0.393 & 0.656 & & 0.039 & 0.109 & 0.051 & 30.831 & 31.315 & 26.909 \\
\hline & \multicolumn{9}{|c|}{ Candidate countries } \\
\hline Bulgaria & & -0.005 & & & 0.384 & & & 24.757 & \\
\hline Romania & & -0.070 & & & 0.114 & & & 30.783 & \\
\hline Turkey & & -0.201 & & & 0.124 & & & 23.740 & \\
\hline Minimum & & -0.201 & & & 0.114 & & & 23.740 & \\
\hline Maximum & & -0.005 & & & 0.34 & & & 30.783 & \\
\hline
\end{tabular}

Note: Hodrick-Prescott Filter with smoothness parameter equal to 6.25.

* We did not consider the years 1991 and 1992 to take into account the Finland crisis in the early 1990s. 
Table 4 - Building and Construction contribution to business cycle synchronisation (vis-à-vis EMU)

\begin{tabular}{|c|c|c|c|c|c|c|c|c|c|}
\hline & \multicolumn{3}{|c|}{$\begin{array}{c}\text { Business Cycle } \\
\text { Synchronization }\end{array}$} & \multicolumn{3}{|c|}{ Volatility } & \multicolumn{3}{|c|}{$\begin{array}{l}\text { Sector share in the country } \\
\text { added value }(\%)\end{array}$} \\
\hline & $80-92$ & $93-05$ & $80-05$ & $80-92$ & $93-05$ & $80-05$ & $80-92$ & $93-05$ & $80-05$ \\
\hline & \multicolumn{9}{|c|}{ EMU countries } \\
\hline Austria & -0.295 & -0.131 & -0.237 & 0.026 & 0.018 & 0.022 & 7.235 & 7.829 & 7.520 \\
\hline Belgium & 0.621 & 0.602 & 0.622 & 0.037 & 0.024 & 0.031 & 5.504 & 4.944 & 5.235 \\
\hline Finland & $0.567^{*}$ & 0.407 & $0.472 *$ & $0.107^{*}$ & 0.102 & $0.105^{*}$ & 7.245 & 5.114 & 6.222 \\
\hline France & 0.476 & 0.433 & 0.477 & 0.029 & 0.029 & 0.029 & 6.894 & 5.562 & 6.255 \\
\hline Germany & 0.391 & 0.088 & 0.248 & 0.044 & 0.034 & 0.039 & 5.935 & 5.571 & 5.760 \\
\hline Greece & 0.231 & -0.130 & 0.108 & 0.056 & 0.036 & 0.047 & 7.583 & 7.443 & 7.516 \\
\hline Ireland & & 0.795 & & & 0.041 & & & 6.657 & \\
\hline Italy & 0.782 & 0.091 & 0.493 & 0.043 & 0.036 & 0.040 & 6.520 & 5.354 & 5.960 \\
\hline Luxembourg & 0.343 & 0.114 & 0.218 & 0.023 & 0.036 & 0.029 & & 6.327 & \\
\hline Netherlands & 0.012 & 0.765 & 0.358 & 0.032 & 0.023 & 0.028 & 5.751 & 5.463 & 5.613 \\
\hline Portugal & 0.104 & 0.696 & 0.152 & 0.113 & 0.041 & 0.085 & 5.664 & 6.691 & 6.157 \\
\hline Spain & 0.463 & 0.658 & 0.516 & 0.077 & 0.036 & 0.062 & 7.348 & 8.258 & 7.785 \\
\hline Minimum & -0.295 & -0.185 & 0.175 & 0.023 & 0.018 & 0.015 & 5.504 & 4.944 & 5.235 \\
\hline \multirow[t]{2}{*}{ Maximum } & 0.782 & 0.815 & 0.679 & 0.113 & 0.102 & 0.058 & 7.583 & 8.258 & 7.7875 \\
\hline & \multicolumn{9}{|c|}{ Other EU } \\
\hline Cyprus & & -0.639 & & & 0.015 & & & 7.738 & \\
\hline Czech Republic & & -0.348 & & & 0.070 & & & 7.474 & \\
\hline Denmark & -0.171 & 0.344 & 0.108 & 0.066 & 0.042 & 0.055 & 5.461 & 5.068 & 5.272 \\
\hline Estonia & & -0.287 & & & 0.039 & & & 6.056 & \\
\hline Hungary & & 0.016 & & & 0.118 & & & 4.917 & \\
\hline Latvia & & 0.459 & & & 0.129 & & & 5.292 & \\
\hline Lithuania & & -0.084 & & & 0.124 & & & 6.888 & \\
\hline Malta & & 0.233 & & & 0.024 & & & 4.678 & \\
\hline Poland & & 0.339 & & & 0.086 & & & 6.898 & \\
\hline Slovakia & & -0.511 & & & 0.119 & & & 5.804 & \\
\hline Slovenia & & 0.244 & & & 0.090 & & & 5.669 & \\
\hline Sweden & 0.726 & 0.436 & 0.601 & 0.075 & 0.061 & 0.071 & 6.112 & 4.356 & 5.269 \\
\hline UK & 0.094 & 0.611 & 0.296 & 0.059 & 0.048 & 0.054 & 6.070 & 5.251 & 5.677 \\
\hline Minimum & -0.171 & -0.639 & 0.108 & 0.059 & 0.015 & 0.054 & 5.461 & 4.356 & 5.269 \\
\hline \multirow[t]{2}{*}{ Maximum } & 0.726 & 0.611 & 0.601 & 0.075 & 0.129 & 0.071 & 6.112 & 7.738 & 5.677 \\
\hline & \multicolumn{9}{|c|}{ Candidate countries } \\
\hline Bulgaria & & 0.025 & & & 0.471 & & & 4.442 & \\
\hline Romania & & -0.207 & & & 0.124 & & & 6.162 & \\
\hline Turkey & & -0.132 & & & 0.162 & & & 5.325 & \\
\hline Minimum & & -0.207 & & & 0.124 & & & 4.442 & \\
\hline Maximum & & 0.025 & & & 0.471 & & & 6.162 & \\
\hline
\end{tabular}

Note: Hodrick-Prescott Filter with smoothness parameter equal to 6.25.

* We did not consider the years 1991 and 1992 to take into account the Finland crisis in the early 1990s. 
Table 5 - Agriculture, Fishery and Forestry contribution to business cycle synchronisation (vis-à-vis EMU)

\begin{tabular}{|c|c|c|c|c|c|c|c|c|c|}
\hline & \multicolumn{3}{|c|}{$\begin{array}{c}\text { Business Cycle } \\
\text { Synchronization }\end{array}$} & \multicolumn{3}{|c|}{ Volatility } & \multicolumn{3}{|c|}{$\begin{array}{l}\text { Sector share in the country } \\
\text { added value }(\%)\end{array}$} \\
\hline & $80-92$ & $93-05$ & $80-05$ & $80-92$ & $93-05$ & $80-05$ & $80-92$ & $93-05$ & $80-05$ \\
\hline & \multicolumn{9}{|c|}{ EMU countries } \\
\hline Austria & -0.139 & 0.546 & 0.183 & 0.032 & 0.024 & 0.028 & 4.412 & 2.335 & 3.415 \\
\hline Belgium & 0.239 & 0.430 & 0.290 & 0.038 & 0.035 & 0.036 & 2.283 & 1.409 & 1.863 \\
\hline Finland & $0.635^{*}$ & 0.431 & $0.507^{*}$ & $0.090 *$ & 0.057 & $0.074 *$ & 6.731 & 3.957 & 5.399 \\
\hline France & -0.023 & 0.305 & 0.083 & 0.035 & 0.026 & 0.030 & 4.176 & 3.001 & 3.612 \\
\hline Germany & 0.196 & 0.530 & 0.295 & 0.056 & 0.046 & 0.050 & 1.706 & 1.233 & 1.479 \\
\hline Greece & 0.150 & -0.179 & 0.032 & 0.112 & 0.042 & 0.084 & 12.396 & 8.054 & 10.312 \\
\hline Ireland & & -0.010 & & & 0.034 & & & 4.697 & \\
\hline Italy & 0.461 & 0.040 & 0.316 & 0.033 & 0.035 & 0.035 & 4.545 & 2.970 & 3.789 \\
\hline Luxembourg & 0.001 & 0.220 & 0.080 & 0.049 & 0.045 & 0.046 & & 0.812 & \\
\hline Netherlands & 0.124 & 0.455 & 0.236 & 0.030 & 0.033 & 0.031 & 4.079 & 2.823 & 3.476 \\
\hline Portugal & -0.071 & -0.006 & -0.054 & 0.047 & 0.035 & 0.041 & 12.871 & 4.751 & 8.974 \\
\hline Spain & 0.197 & 0.052 & 0.205 & 0.053 & 0.041 & 0.048 & 5.926 & 4.422 & 5.204 \\
\hline Minimum & -0.139 & -0.179 & -0.054 & 0.032 & 0.024 & 0.028 & 1.706 & 2.335 & 1.863 \\
\hline \multirow[t]{2}{*}{ Maximum } & 0.635 & 0.546 & 0.507 & 0.112 & 0.057 & 0.084 & 12.871 & 1.409 & 10.312 \\
\hline & \multicolumn{9}{|c|}{ Other EU } \\
\hline Cyprus & & 0.222 & & & 0.039 & & & 3.992 & \\
\hline Czech Republic & & 0.054 & & & 0.054 & & & 4.041 & \\
\hline Denmark & -0.026 & 0.386 & 0.180 & 0.050 & 0.083 & 0.066 & 4.584 & 2.755 & 3.706 \\
\hline Estonia & & -0.061 & & & 0.029 & & & 6.580 & \\
\hline Hungary & & -0.173 & & & 0.084 & & & 5.209 & \\
\hline Latvia & & 0.565 & & & 0.111 & & & 5.992 & \\
\hline Lithuania & & 0.090 & & & 0.131 & & & 9.361 & \\
\hline Malta & & 0.113 & & & 0.037 & & & 2.570 & \\
\hline Poland & & 0.055 & & & 0.097 & & & 6.146 & \\
\hline Slovakia & & -0.092 & & & 0.060 & & & 5.136 & \\
\hline Slovenia & & 0.251 & & & 0.090 & & & 3.622 & \\
\hline Sweden & 0.446 & 0.188 & 0.293 & 0.042 & 0.058 & 0.050 & 3.780 & 2.189 & 3.016 \\
\hline UK & 0.055 & 0.073 & 0.037 & 0.044 & 0.028 & 0.036 & 1.867 & 1.298 & 1.594 \\
\hline Minimum & -0.026 & -0.173 & 0.037 & 0.042 & 0.028 & 0.036 & 1.867 & 1.298 & 3.706 \\
\hline \multirow[t]{2}{*}{ Maximum } & 0.446 & 0.386 & 0.293 & 0.050 & 0.131 & 0.066 & 4.584 & 9.361 & 1.594 \\
\hline & \multicolumn{9}{|c|}{ Candidate countries } \\
\hline Bulgaria & & -0.064 & & & 0.270 & & & 15.367 & \\
\hline Romania & & -0.307 & & & 0.116 & & & 15.823 & \\
\hline Turkey & & -0.274 & & & 0.165 & & & 13.945 & \\
\hline Minimum & & -0.307 & & & 0.116 & & & 13.945 & \\
\hline Maximum & & -0.064 & & & 0.270 & & & 15.823 & \\
\hline
\end{tabular}

Note: Hodrick-Prescott Filter with smoothness parameter equal to 6.25.

* We did not consider the years 1991 and 1992 to take into account the Finland crisis in the early 1990s. 
Table 6 - Services contribution to business cycle synchronisation (vis-à-vis EMU)

\begin{tabular}{|c|c|c|c|c|c|c|c|c|c|}
\hline & \multicolumn{3}{|c|}{$\begin{array}{c}\text { Business Cycle } \\
\text { Synchronization }\end{array}$} & \multicolumn{3}{|c|}{ Volatility } & \multicolumn{3}{|c|}{$\begin{array}{l}\text { Sector share in the country } \\
\text { added value }(\%)\end{array}$} \\
\hline & $80-92$ & $93-05$ & $80-05$ & $80-92$ & $93-05$ & $80-05$ & $80-92$ & 93-05 & $80-05$ \\
\hline & \multicolumn{9}{|c|}{ EMU countries } \\
\hline Austria & -0.338 & 0.286 & -0.074 & 0.017 & 0.016 & 0.016 & 63.614 & 66.748 & 65.119 \\
\hline Belgium & 0.092 & 0.370 & 0.203 & 0.021 & 0.014 & 0.018 & 65.842 & 71.675 & 68.642 \\
\hline Finland & $0.464 *$ & 0.303 & $0.368^{*}$ & $0.041 *$ & 0.051 & $0.046^{*}$ & 59.543 & 65.516 & 62.410 \\
\hline France & 0.254 & 0.507 & 0.360 & 0.012 & 0.010 & 0.011 & 66.619 & 73.732 & 70.034 \\
\hline Germany & 0.197 & 0.170 & 0.171 & 0.019 & 0.015 & 0.017 & 59.807 & 69.222 & 64.326 \\
\hline Greece & 0.226 & -0.235 & 0.039 & 0.049 & 0.018 & 0.037 & 60.036 & 69.839 & 64.741 \\
\hline Ireland & & -0.127 & & & 0.029 & & & 56.218 & \\
\hline Italy & 0.787 & 0.217 & 0.527 & 0.026 & 0.031 & 0.029 & 61.502 & 68.159 & 64.697 \\
\hline Luxembourg & -0.236 & 0.250 & 0.012 & 0.018 & 0.024 & 0.020 & & 80.403 & \\
\hline Netherlands & -0.414 & 0.444 & -0.019 & 0.020 & 0.014 & 0.017 & 65.270 & 71.813 & 68.410 \\
\hline Portugal & 0.428 & 0.550 & 0.311 & 0.066 & 0.022 & 0.049 & 60.686 & 68.554 & 64.463 \\
\hline Spain & 0.643 & 0.586 & 0.576 & 0.044 & 0.019 & 0.036 & 61.480 & 62.045 & 61.752 \\
\hline Minimum & -0.414 & -0.235 & -0.074 & 0.017 & 0.010 & 0.011 & 59.543 & 56.218 & 61.752 \\
\hline \multirow[t]{2}{*}{ Maximum } & 0.787 & 0.586 & 0.576 & 0.066 & 0.051 & 0.049 & 65.270 & 80.403 & 70.034 \\
\hline & \multicolumn{9}{|c|}{ Other EU } \\
\hline Cyprus & & 0.840 & & & 0.015 & & & 75.267 & \\
\hline Czech Republic & & -0.235 & & & 0.035 & & & 57.159 & \\
\hline Denmark & -0.292 & 0.152 & -0.062 & 0.016 & 0.008 & 0.013 & 69.093 & 71.921 & 70.450 \\
\hline Estonia & & -0.102 & & & 0.018 & & & 60.771 & \\
\hline Hungary & & -0.225 & & & 0.106 & & & 58.816 & \\
\hline Latvia & & 0.520 & & & 0.062 & & & 66.786 & \\
\hline Lithuania & & 0.432 & & & 0.110 & & & 58.635 & \\
\hline Malta & & 0.647 & & & 0.034 & & & 66.745 & \\
\hline Poland & & 0.073 & & & 0.077 & & & 58.814 & \\
\hline Slovakia & & -0.402 & & & 0.049 & & & 60.293 & \\
\hline Slovenia & & 0.297 & & & 0.073 & & & 60.225 & \\
\hline Sweden & 0.797 & 0.325 & 0.535 & 0.041 & 0.049 & 0.045 & 65.268 & 69.361 & 67.233 \\
\hline UK & 0.340 & 0.568 & 0.411 & 0.034 & 0.046 & 0.040 & 61.231 & 70.219 & 65.546 \\
\hline Minimum & -0.292 & -0.402 & -0.062 & 0.016 & 0.008 & 0.024 & 61.231 & 58.814 & 65.546 \\
\hline \multirow[t]{2}{*}{ Maximum } & 0.797 & 0.840 & 0.535 & 0.041 & 0.110 & 0.051 & 69.093 & 75.267 & 70.450 \\
\hline & \multicolumn{9}{|c|}{ Candidate countries } \\
\hline Bulgaria & & 0.027 & & & 0.426 & & & 55.109 & \\
\hline Romania & & -0.140 & & & 0.089 & & & 47.233 & \\
\hline Turkey & & -0.196 & & & 0.147 & & & 56.956 & \\
\hline Minimum & & -0.196 & & & 0.089 & & & 47.233 & \\
\hline Maximum & & 0.027 & & & 0.426 & & & 55.109 & \\
\hline
\end{tabular}

Note: Hodrick-Prescott Filter with smoothness parameter equal to 6.25.

* We did not consider the years 1991 and 1992 to take into account the Finland crisis in the early 1990s. 


\section{Appendix 1 - Filtering Methods}

Letting $y_{i, t}=\ln \left(Y_{i, t}\right)$, the first measure is simple differencing (growth rate of the real GDP):

$$
c_{i, t}=y_{i, t}-y_{i, t-1} \text {. }
$$

The second and the third method used in the empirical analysis make use of the HodrickPrescott (HP) filter, proposed by Hodrick and Prescott (1980). The filter decomposes the series into a cyclical $\left(c_{i, t}\right)$ and a trend $\left(g_{i, t}\right)$ component, by minimizing with respect to $g_{i, t}$, for the smoothness parameter $\lambda>0$ the following quantity:

$$
\sum_{t=1}^{T}\left(y_{i, t}-g_{i, t}\right)^{2}+\lambda \sum_{t=2}^{T-1}\left(g_{i, t+1}-g_{i, t-1}\right)^{2} .
$$

The fourth method makes use of the recently very popular Band-Pass (BP) filter proposed by Baxter and King (1995), and evaluated by Stock and Watson (1998) and Christiano and Fitzgerald (1999) that also compares its properties to those of the HP filter. The low pass (LP) filter $\alpha(L)$, which forms the basis for the band pass filter, selects a finite number of moving average weights $\alpha_{h}$ to minimize:

$$
Q=\int_{-\pi}^{\pi}|\delta(\omega)|^{2} d \omega
$$

where $\alpha(L)=\sum_{h=-K}^{K} \alpha_{h} L^{h}$ and $\alpha_{K}(\omega)=\sum_{h=-K}^{K} \alpha_{h} e^{-i \omega h}$.

The LP filter uses $\alpha_{K}(\omega)$ to approximate the infinite MA filter $\beta(\omega)$. Defining $\delta(\omega) \equiv \beta(\omega)-\alpha(\omega)$, and then minimizing $Q$, we minimize the discrepancy between the ideal LP filter $\beta(\omega)$ and its finite representation $\alpha_{K}(\omega)$ at frequency $\omega$. The main objective of the BP filter as implemented by Baxter and King (1995) is to remove both the high frequency and low frequency component of a series, leaving the business-cycle frequencies. This is obtained by subtracting the weights of two low pass filters. We define $\omega_{L}$ and $\omega_{H}$, the lower and upper frequencies of two low pass filters as respectively eight and two for annual data. We therefore remove all fluctuations shorter than two or longer than eight years. The frequency representation of the band pass weights becomes $\alpha_{K}\left(\omega_{H}\right)-\alpha_{K}\left(\omega_{L}\right)$, and forms the basis of the Baxter-King filter, which provides an alternative estimate of the trend and the cyclical component. 


\section{Appendix 2 - Within Country Sectoral Synchronization}

It is easy to show that the sectoral business cycle synchronization within country is linked with the EMU-sector $(j)$ synchronization via the EMU-country $(i)$ synchronization. Indeed, we computed $\operatorname{corr}\left(c_{E M U}, c_{i}\right)=\frac{\sigma\left(c_{E M U}, c_{i}\right)}{\sigma_{c_{E M U}} \sigma_{c_{i}}}$ and $\operatorname{corr}\left(c_{E M U}, c_{i}^{j}\right)=\frac{\sigma\left(c_{E M U}, c_{i}^{j}\right)}{\sigma_{c_{E M U}} \sigma_{c_{i}^{j}}}$, but we can also disaggregate $\operatorname{corr}\left(c_{E M U}, c_{i}^{j}\right)$ as follows:

$$
\operatorname{corr}\left(c_{E M U}, c_{i}^{j}\right)=\frac{\sigma\left(c_{E M U}, c_{i}^{j}\right)}{\frac{\sigma\left(c_{E M U}, c_{i}\right)}{\sigma_{c_{i}} \operatorname{corr}\left(c_{E M U}, c_{i}\right)} \frac{\sigma\left(c_{i}, c_{i}^{j}\right)}{\sigma_{c_{i}} \operatorname{corr}\left(c_{i}, c_{i}^{j}\right)}}
$$

which allows highlighting the contributions of both $\operatorname{corr}\left(c_{i}, c_{i}^{j}\right)$ and of $\operatorname{corr}\left(c_{E M U}, c_{i}\right)$ to $\operatorname{corr}\left(c_{E M U}, c_{i}^{j}\right)$. Therefore, we also computed the within country sectoral business cycle synchronization, $\operatorname{corr}\left(c_{i}, c_{i}^{j}\right)$, which we report below. 
Table A1-Within Country Sectoral Synchronization: Industry; Building and Construction

\begin{tabular}{|c|c|c|c|c|c|c|}
\hline & \multicolumn{3}{|c|}{ Industry } & \multicolumn{3}{|c|}{ Building and Construction } \\
\hline & $80-92$ & $93-05$ & $80-05$ & $80-92$ & $93-05$ & $80-05$ \\
\hline & \multicolumn{6}{|c|}{ EMU countries } \\
\hline Austria & 0.611 & 0.617 & 0.605 & 0.352 & 0.301 & 0.310 \\
\hline Belgium & 0.543 & 0.707 & 0.614 & 0.693 & 0.599 & 0.644 \\
\hline Finland & $0.922 *$ & 0.742 & $0.839^{*}$ & $0.769 *$ & 0.900 & $0.813 *$ \\
\hline France & 0.193 & 0.865 & 0.495 & 0.172 & 0.407 & 0.300 \\
\hline Germany & 0.505 & 0.427 & 0.453 & 0.754 & 0.598 & 0.680 \\
\hline Greece & 0.517 & 0.271 & 0.490 & 0.593 & 0.121 & 0.495 \\
\hline Ireland & & 0.831 & & & 0.789 & \\
\hline Italy & 0.848 & 0.390 & 0.618 & 0.358 & 0.096 & 0.271 \\
\hline Luxembourg & 0.450 & 0.334 & 0.398 & 0.213 & 0.236 & 0.233 \\
\hline Netherlands & 0.471 & 0.214 & 0.356 & 0.163 & 0.592 & 0.320 \\
\hline Portugal & 0.611 & 0.713 & 0.647 & 0.773 & 0.887 & 0.760 \\
\hline Spain & 0.647 & 0.737 & 0.702 & 0.801 & 0.835 & 0.805 \\
\hline Minimum & 0.193 & 0.21 & 0.36 & 0.163 & 0.10 & 0.23 \\
\hline \multirow[t]{2}{*}{ Maximum } & 0.922 & 0.86 & 0.84 & 0.801 & 0.0 & 0.81 \\
\hline & \multicolumn{6}{|c|}{ Other EU } \\
\hline Cyprus & & 0.437 & & & -0.276 & \\
\hline Czech Republic & & 0.752 & & & 0.442 & \\
\hline Denmark & 0.837 & 0.670 & 0.763 & 0.743 & 0.498 & 0.658 \\
\hline Estonia & & 0.646 & & & 0.635 & \\
\hline Hungary & & -0.193 & & & -0.012 & \\
\hline Latvia & & 0.195 & & & 0.223 & \\
\hline Lithuania & & 0.829 & & & 0.658 & \\
\hline Malta & & 0.830 & & & 0.229 & \\
\hline Poland & & -0.344 & & & -0.149 & \\
\hline Slovakia & & 0.323 & & & 0.755 & \\
\hline Slovenia & & 0.852 & & & 0.784 & \\
\hline Sweden & 0.667 & 0.841 & 0.783 & 0.351 & 0.688 & 0.529 \\
\hline UK & 0.189 & 0.536 & 0.262 & 0.519 & 0.576 & 0.504 \\
\hline Minimum & 0.189 & -0.344 & 0.26 & 0.351 & -0.276 & 0.504 \\
\hline \multirow[t]{2}{*}{ Maximum } & 0.837 & 0.852 & 0.78 & 0.743 & 0.784 & 0.658 \\
\hline & \multicolumn{6}{|c|}{ Candidate countries } \\
\hline Bulgaria & & 0.345 & & & 0.370 & \\
\hline Romania & & 0.677 & & & 0.640 & \\
\hline Turkey & & 0.668 & & & 0.676 & \\
\hline Minimum & & 0.345 & & & 0.370 & \\
\hline Maximum & & 0.677 & & & 0.676 & \\
\hline
\end{tabular}

Note: Hodrick-Prescott Filter with smoothness parameter equal to 6.25.

* We did not consider the years 1991 and 1992 to take into account the Finland crisis in the early 1990s. 
Table A2 - Within Country Sectoral Synchronization: Agriculture; Services

\begin{tabular}{|c|c|c|c|c|c|c|}
\hline & \multicolumn{3}{|c|}{$\begin{array}{l}\text { Agriculture, Fishery and } \\
\text { Forestry }\end{array}$} & \multicolumn{3}{|c|}{ Services } \\
\hline & $80-92$ & $93-05$ & $80-05$ & $80-92$ & $93-05$ & $80-05$ \\
\hline & \multicolumn{6}{|c|}{ EMU countries } \\
\hline Austria & 0.056 & 0.218 & 0.124 & 0.220 & 0.199 & 0.186 \\
\hline Belgium & 0.336 & 0.356 & 0.346 & 0.038 & 0.242 & 0.107 \\
\hline Finland & $0.719 *$ & 0.584 & $0.682 *$ & $0.611^{*}$ & 0.791 & $0.677^{*}$ \\
\hline France & 0.286 & 0.412 & 0.328 & 0.050 & 0.432 & 0.202 \\
\hline Germany & -0.004 & 0.412 & 0.087 & 0.696 & 0.664 & 0.649 \\
\hline Greece & 0.499 & 0.350 & 0.483 & 0.212 & 0.506 & 0.253 \\
\hline Ireland & & -0.089 & & & 0.465 & \\
\hline Italy & 0.186 & 0.113 & 0.185 & 0.570 & 0.174 & 0.383 \\
\hline Luxembourg & -0.146 & 0.191 & 0.009 & 0.072 & 0.006 & 0.037 \\
\hline Netherlands & 0.122 & 0.296 & 0.223 & -0.134 & 0.314 & 0.018 \\
\hline Portugal & 0.442 & 0.172 & 0.363 & 0.691 & 0.801 & 0.684 \\
\hline Spain & 0.664 & 0.284 & 0.545 & 0.532 & 0.773 & 0.595 \\
\hline Minimum & -0.146 & -0.08 & 0.009 & -0.134 & 0.006 & 0.018 \\
\hline \multirow[t]{2}{*}{ Maximum } & 0.719 & 0.584 & 0.682 & 0.696 & 0.801 & 0.684 \\
\hline & \multicolumn{6}{|c|}{ Other EU } \\
\hline Cyprus & & 0.441 & & & 0.470 & \\
\hline Czech Republic & & 0.632 & & & 0.165 & \\
\hline Denmark & 0.079 & 0.459 & 0.273 & 0.805 & 0.342 & 0.641 \\
\hline Estonia & & 0.627 & & & 0.664 & \\
\hline Hungary & & -0.196 & & & -0.256 & \\
\hline Latvia & & 0.195 & & & 0.027 & \\
\hline Lithuania & & 0.887 & & & 0.658 & \\
\hline Malta & & 0.160 & & & 0.652 & \\
\hline Poland & & -0.338 & & & -0.634 & \\
\hline Slovakia & & 0.464 & & & 0.514 & \\
\hline Slovenia & & 0.628 & & & 0.798 & \\
\hline Sweden & 0.487 & 0.760 & 0.669 & 0.144 & 0.639 & 0.458 \\
\hline UK & 0.443 & 0.466 & 0.441 & -0.030 & 0.212 & 0.045 \\
\hline Minimum & 0.079 & -0.338 & 0.273 & -0.030 & -0.634 & 0.641 \\
\hline \multirow[t]{2}{*}{ Maximum } & 0.487 & 0.887 & 0.669 & 0.805 & 0.798 & 0.045 \\
\hline & \multicolumn{6}{|c|}{ Candidate countries } \\
\hline Bulgaria & & 0.302 & & & 0.355 & \\
\hline Romania & & 0.703 & & & 0.431 & \\
\hline Turkey & & 0.749 & & & 0.716 & \\
\hline Minimum & & 0.302 & & & 0.355 & \\
\hline Maximum & & 0.749 & & & 0.716 & \\
\hline
\end{tabular}

Note: Hodrick-Prescott Filter with smoothness parameter equal to 6.25.

* We did not consider the years 1991 and 1992 to take into account the Finland crisis in the early 1990s. 
Table B1 - Data sources

\begin{tabular}{lc}
\hline \multicolumn{1}{c}{ Original series } & AMECO codes * \\
\hline $\begin{array}{l}\text { Gross domestic product at } 2000 \text { market prices - National currency: Data at constant } \\
\text { prices. }\end{array}$ & 1.1 .0 .0 .0 GD \\
Price deflator gross domestic product at market prices - National currency; 2000 = & $3.1 .0 .0 . P V G D$ \\
100. Ratio: Data at current prices/Data at constant prices & \\
Gross Value Added at current prices; agriculture, forestry and fishery products - & $1.0 .99 .0 . U V G 1$ \\
National currency: Data at current prices & \\
Gross value added at current prices; industry excluding building and construction - & $1.0 .99 .0 . U V G 2$ \\
National Currency: Data at current prices \\
Gross value added at current prices; building and construction - National Currency: \\
Data at current prices \\
Gross value added at current prices; services - National currency: Data at current \\
prices
\end{tabular}

Note: * series from the EC AMECO database.

Table B2 - Data availability

\begin{tabular}{|c|c|c|c|c|c|}
\hline & GDP & I & $\mathrm{BC}$ & $\mathrm{AFF}$ & $\mathrm{S}$ \\
\hline Austria & 1980 & 1980 & 1980 & 1980 & 1980 \\
\hline Belgium & 1980 & 1980 & 1980 & 1980 & 1980 \\
\hline Finland & 1980 & 1980 & 1980 & 1980 & 1980 \\
\hline France & 1980 & 1980 & 1980 & 1980 & 1980 \\
\hline Germany & 1980 & 1980 & 1980 & 1980 & 1980 \\
\hline Greece & 1980 & 1980 & 1980 & 1980 & 1980 \\
\hline Ireland & 1980 & 1990 & 1990 & 1990 & 1990 \\
\hline Italy & 1980 & 1980 & 1980 & 1980 & 1980 \\
\hline Luxembourg & 1980 & 1985 & 1985 & 1985 & 1985 \\
\hline Netherlands & 1980 & 1980 & 1980 & 1980 & 1980 \\
\hline Portugal & 1980 & 1980 & 1980 & 1980 & 1980 \\
\hline Spain & 1980 & 1980 & 1980 & 1980 & 1980 \\
\hline Cyprus & 1990 & 1995 & 1995 & 1995 & 1995 \\
\hline Czech Republic & 1990 & 1990 & 1990 & 1990 & 1990 \\
\hline Denmark & 1980 & 1980 & 1980 & 1980 & 1980 \\
\hline Estonia & 1993 & 1993 & 1993 & 1993 & 1993 \\
\hline Hungary & 1991 & 1991 & 1991 & 1991 & 1991 \\
\hline Latvia & 1990 & 1992 & 1992 & 1992 & 1992 \\
\hline Lithuania & 1990 & 1992 & 1992 & 1992 & 1992 \\
\hline Malta & 1990 & 1990 & 1990 & 1990 & 1990 \\
\hline Poland & 1990 & 1991 & 1991 & 1991 & 1991 \\
\hline Slovakia & 1992 & 1993 & 1993 & 1993 & 1993 \\
\hline Slovenia & 1990 & 1991 & 1991 & 1991 & 1991 \\
\hline Sweden & 1980 & 1980 & 1980 & 1980 & 1980 \\
\hline United Kingdom & 1980 & 1980 & 1980 & 1980 & 1980 \\
\hline Bulgaria & 1991 & 1996 & 1996 & 1996 & 1996 \\
\hline Romania & 1990 & 1995 & 1995 & 1995 & 1995 \\
\hline Turkey & 1980 & 1980 & 1980 & 1980 & 1980 \\
\hline
\end{tabular}

Note: In the table is reported the first year where the data is available.

$\mathrm{GDP}=$ gross domestic product; I= gross value added - industry excluding building and construction;

$\mathrm{BC}=$ gross value added - building and; $\mathrm{AFF}=$ gross value added - agriculture, forestry and fishery products; $\mathrm{S}=$ gross value added - services. 